\title{
Identification of Suitable Reference Genes for Expression Studies in Pomegranate Under Different Biotic and Abiotic Stress Conditions
}

\author{
Puspha Doddaraju \\ University of Horticultural Sciences \\ Pavan Kumar \\ University of Horticultural Sciences \\ Mahesh S Dashyal \\ University of Horticultural Sciences \\ Manjunath Girigowda ( $\square$ gmanjunath2007@gmail.com ) \\ University of Horticultural Sciences https://orcid.org/0000-0002-0976-1477
}

\section{Research Article}

Keywords: Reference genes, qPCR, bacterial blight, wilt, nematode, water stress, cold and Pomegranate

Posted Date: March 10th, 2021

DOI: https://doi.org/10.21203/rs.3.rs-259407/v1

License: (c) (i) This work is licensed under a Creative Commons Attribution 4.0 International License. Read Full License 


\section{Abstract}

Pomegranate (Punica granatum) is an important economic fruit crop, facing many biotic and abiotic challenges during cultivation. Several research programs are in progress to understand both biotic and abiotic stress factors and mitigate these challenges using gene expression studies based on the qPCR approach. However, research publications are not available yet to select the standard reference gene for normalizing target gene expression values in pomegranate. The most suitable candidate reference gene is required to ensure precise and reliable results for qPCR analysis. In the current research, eight candidate reference genes' stability was evaluated under different stress conditions using different algorithms such as $\Delta \mathrm{Ct}$, geNorm, BestKeeper, NormFinder and RefFinder. The various algorithms revealed that EFA1 and 18S rRNA were common and most stable reference genes (RGs) under abiotic and wilt stress. Whereas comprehensive ranking by RefFinder showed GAPDH and CYPF were the most stable RGs under combined biotic (pooled samples of all biotic stress) and bacterial blight samples. The two most stable reference genes are adequate for normalizing target gene expression under wilt, nematode, bacterial blight and abiotic stress conditions using qPCR. The above data provide comprehensive details for the selection of a candidate reference gene in various stresses in pomegranate

\section{Introduction}

Pomegranate (Punica granatum L.) is an important fruit crop of the world's subtropical and tropical regions. It has been used in traditional medicine to cure many diseases across different cultures and civilizations [1]. At the global level, India is the leading producer of pomegranate, with a yearly production of 2,442 thousand tonnes grown in 209 thousand hectares. However, pomegranate production has been hampered by various biotic and abiotic factors leading to severe yield loss in quality and quantity. Major biotic and abiotic factors include bacterial blight caused by Xanthomonas citri pv. punicae [2], wilt caused by Ceratocystis fimbriata [3], drought [4], and cold, respectively. Understanding the plant's underlying mechanisms to these stresses with detailed molecular studies through gene expression analyses is essential.

The gene expression analysis requires the most sensitive, accurate, and reproducible measurements for specific mRNA sequences. Real-time qPCR is emerged as the most sensitive yet powerful technique to study mRNA abundances and quantifying gene expression [5, 6]. The gene expression studies required good reference genes for consistent and reproducible results. These genes are essential for maintaining the cell's basic functioning and are stably expressed regardless of developmental stage or environmental conditions. Presently, the normalization of quantitative gene expression is carried out by several traditional reference genes, including 18S [7], Actin [8], GAPDH [9], and CYP [9]. However, in pomegranate reference genes such as 18S rRNA, Ribosomal protein S, named PgRPSIl, and GAPDH has been used for gene normalization in various gene expression studies [10-12]. However, this may misinterpret the gene expression because all reference genes may not constantly express in different tissues under diverse environmental conditions. Both abiotic and biotic stresses are the major factors affecting gene expression, and wide variation exists in the expression of RGs under stress conditions [13]. Therefore, it is essential to identify the most stable reference genes to measure differentially expressed target genes.

Recently Pomegranate chloroplast and whole-genome have been sequenced, although a significant portion of the genome has been annotated [14, 15], most of the genes remain functionally uncharacterized. In spite of being widely cultivated in India and other parts of the world, investigation on the molecular basis of biotic and abiotic stress is limited. It is a prerequisite to functionally characterize stress-associated genes by identifying the stable reference genes for different stress. Thus, the present study identifies the candidate reference gene for biotic stress such as bacterial blight, wilt, and abiotic stress such as drought and cold stress in pomegranate.

\section{Materials And Methods Plant material}

Three varieties of pomegranate viz., Bhagwa, Nana, and Daru were grown using stem cuttings approximately $12 \mathrm{~cm}$ long in plastic pots filled with vermicompost, soil, and sand (1:1:3) and maintained at $29 \pm 2{ }^{\circ} \mathrm{C}$ at a relative humidity of $60-80 \%$ in the greenhouse. One-year-old plants were used to carry out experiments for biotic and abiotic stress. Bhagwa, Nana, and Dharu were used for the bacterial blight experiment and only Bhagwa was used in other experiments. Experimental units were arranged in a completely randomized design with five replications.

\section{Biotic Stress}

\section{Bacterial blight infection}

Pure and a single colony of XAP (Accession no. KX702398.1) culture was grown on NGA medium ( $0.5 \%$ proteus peptone, $0.3 \%$ beef extract, and $0.25 \%$ sucrose) for $48 \mathrm{hrs}$ at $2 \pm 0.5^{\circ} \mathrm{C}$. The bacterial concentration was set for $0.3 \mathrm{OD}$ at $\mathrm{A}_{600} \mathrm{~nm}$ using Bio-Spectrometer (Eppendorf AG, Hamburg, Germany). The XAP was spray inoculated on pomegranate plants (Bhagwa, Nana and Dharu) according to [16]. Leaves samples were collected 10 days post pathogen inoculation for reference gene identification. 


\section{Nematode infection}

The root-knot nematode $M$. incognita, was used for the experiment, according to [17]. Nematode population was maintained on the tomato plants (Lycopersicon esculentum) and Non -sterile egg masses were collected in a $2 \mathrm{ml}$ tube containing 500 ml of sterile distilled water. The suspension was centrifuged at $1000 \mathrm{~g}$ for $5 \mathrm{~min}$. The supernatant collected was re-suspended in $5 \mathrm{ml}$ sterile distilled water and ready to use. Pomegranate plant (cv. Bhagwa) was inoculated with1000 J2 stage M. incognita and control plants were inoculated with water and then maintained for approximately 25 to 30 days under greenhouse conditions.

\section{Wilt infection}

Ceratocystis fimbriata (UHS-CF5, Acc. No KU877189) grown on Potato dextrose broth at $25 \pm 0.5{ }^{\circ} \mathrm{C}$, with a photoperiod of $12 \mathrm{~h}$ for 7 days. Before inoculation of the pathogen, plants were wounded on the xylem using cork bore to facilitate the pathogen entry. The pathogen was then artificially inoculated by soil drenching using a $30 \mathrm{ml}$ inoculum with spore concentrations of $4 \times 108$ spores/ml. Plants treated with water were maintained as control.

\section{Abiotic stress}

\section{Cold stress}

One-year-old Bhagwa plants were subjected to cold stress. Cold treatment was performed by keeping plants at $4{ }^{\circ} \mathrm{C}$ for 48 hrs in the cold growth chamber. Leaves were sampled at $42 \mathrm{hr}$ post-stress imposition of the stress and immediately flash feezed in liquid nitrogen and stored at $-80{ }^{\circ} \mathrm{C}$ until use.

\section{Water stress}

In the greenhouse, six-months-old pomegranate plants of Bhagwa variety were subjected to water-limited conditions. All plants were maintained at field capacity before the imposition of water stress. Control plants were maintained at field capacity throughout the experiment according to the protocol described by [18], whereas water-stressed plants were subjected to a water-limited condition for 12 days by withholding until the plants showed a wilting symptom. Leaves were sampled at 12 days post-stress imposition and immediately frozen in liquid nitrogen and stored at $-80 \mathrm{C}$ until use.

\section{RNA isolation and first-strand cDNA synthesis}

Total RNA was isolated using RNeasy plant mini kit (Sigma, USA) according to the manufacturer's protocol, for root sample incubation period was extended for an additional 15 minutes. Further, post RNA isolation samples were treated with RNase-free DNase I (Thermo Fisher, MA, USA) to remove DNA contamination. The purity of RNA was measured by taking the observance at 260/280 nm using NanoDrop Spectrophotometer (ND1000 Thermo Fisher, MA, USA). cDNA synthesis was performed taking $1 \mu \mathrm{g}$ of total RNA in a $20 \mu \mathrm{l}$ reaction using maxima first strand cDNA Synthesis Kit (ThermoFisher, K1672, USA) following manual instruction. Constructed cDNA sample was diluted 10 times with nuclease-free water and stored at $-20^{\circ} \mathrm{C}$ for qPCR analysis.

\section{Reference gene selection and primer design}

Eight candidate reference genes viz., a-tubulin, $\beta$-tubulin, GAPDH, CYPF, PPCT, EF1-A, 18S rRNA, and UBQ (Table 1), were chosen in the present study. The primers were designed based on the pomegranate gene sequences (http://www.ncbi.nlm) using Oligo Explorer software (version 1.1.0). Primer sequence homology was validated using the BlastN program.

\section{RT-qPCR}

All the quantitative reverse transcription-polymerase chain reaction (RT-qPCR) reactions were performed using SYBR Green I technology, on StepOne plus a real-time PCR machine (Applied Biosystems, USA). A cocktail mixture for each PCR reaction was constituted of 1X Power UP SYBR Green master mix (Thermo Fisher Scientific), $0.5 \mu \mathrm{M}$ primers (forward and reverse primers), and $2 \mu \mathrm{L}$ of tenfold diluted cDNA to the reaction volume of 10 $\mu \mathrm{L}$. The following PCR condition was used: initial denaturation for 30 seconds at $95^{\circ} \mathrm{C}$, followed by 40 cycles of $95^{\circ} \mathrm{C}$ for 10 seconds, $60{ }^{\circ} \mathrm{C}$ for 30 seconds, and $72{ }^{\circ} \mathrm{C}$ for 30 seconds. All the samples were carried out in three replicates with the same cDNA preparation and the total mean was considered for analysis. To determine gene-specific PCR efficiency (E), 10-fold serial dilutions (1-1000) of bulked cDNA were used for generating a

Page 3/12 
standard curve for each gene and each stress condition. Amplification efficiency (E) of each primer was determined by linear regression model according to the equation $\mathrm{E}(\%)=(10-1 /$ slope-1) $\times 100 \%[19]$. The efficiency of the PCR products was calculated by measuring the CT to a specific threshold of each gene [20].

\section{Data mining and statistical analysis to determine the expression stability}

Standard curves were generated from a 5-fold series dilution sample from pooled cDNA as a template for each primer, in three replicates. The melting curves of each primer pairs are shown in Fig. 1. The stabilities of selected reference genes were evaluated using Microsoft Excel-based software tools, NormFinder [21], BestKeeper [22], geNorm [23]. BestKeeper program calculates the stability of the expressed gene using raw data i.e., ct values, the geNorm software program analysis based on the stability of the expressed values (M) and ranks the gene order. Lower the $M$ value (stability value), higher is the stability of any gene expression, $\mathrm{M}$ value less than 1.5 considered as ideal reference genes in all stress conditions. NormFinder calculates the stability of expressed gene based on intra- and inter-group variations and gives the gene rank order by combining these values, lower the rank higher is the stability of any expressed gene. RefFinder performed comprehensive analysis using the data from geNorm (M values), NormFinder (Stability values), BestKeeper (CV and SD), and $\Delta$ Ct values.

\section{Results}

\section{Primer specificity and PCR amplification efficiency for each candidate reference gene}

To identify appropriate reference genes for pomegranate under biotic and abiotic stress, eight candidate reference genes such as EFA1, CYPF, UBQ, $\beta T U B, a T U B, G A P D H, 18 S$, and PPCT were selected based on the previous studies on various plant species. The selected reference gene sequences were obtained from the National Centre for Biotechnology Information (NCBI, USA). The products of these eight reference genes were associated with a wide variety of biological functions of plants. To check the primer specificity for these candidate reference genes, we performed melting curve analysis using qPCR and agarose gel electrophoresis. The PCR product of each primer pair exhibited a single peak in the melting curve and a single band with the expected size after agarose gel electrophoresis (Fig. 1 \& S1). The amplification efficiency for the eight candidate reference genes ranged from $90.65 \%(G A P D H)$ to $103.04 \%$ (PPCT), and correlation coefficient (R2) values ranged from0.981 (GAPDH) to 0.999 (EF1-a and 18S rRNA) (Table 1).

\section{Delta-Ct $(\Delta \mathrm{Ct})$}

The stability of reference gene using delta-Ct analysis, which was represented by the standard deviation (SD). The ranking of reference genes based on the $\Delta \mathrm{Ct}$ method is presented in Table 2 . According to the $\Delta \mathrm{Ct}$ analysis, EFA1 was the most stable reference genes with low SD under all the stress conditions, except under wilt infection. 18S rRNA showed stable expression under wilt infection with a standard deviation of 1.27.

\section{Best keeper}

Data on reference gene expression was reanalyzed using BestKeeper to identify stable reference genes (Pfaffl et al. 2004). The analysis revealed that GAPDH was the most stable gene in both biotic stress and bacterial blight infection with a standard deviation (S.D) of 0.22 and 0.73 respectively (Table 3). Pairwise correlation between the reference gene was performed by the best keeper algorithm to calculate the stability of individual gene. Alpha tubulin showed the most stable expression under abiotic stress with the least S.D of 0.05.

\section{NormFinder}

NormFinder is excel based application, which calculates expression stability for individual reference gene based on variance analysis. A higher stability value of the reference gene indicates a more unstablility, whereas a lower stable value indicates greater gene stability. According to Norm Finder the stability analysis (Table 4), EFA1 occupied the top position with a stability value of 0.07 and 0.12 in abiotic and bacterial blight. CYPF, $18 \mathrm{~S}$, and $\beta$ TUB were the two most stable genes under biotic, wilt, and nematode respectively.

\section{geNorm}

geNorm algorithm calculated the average gene stability ( $M$ value) of eight candidate reference genes. Similar to NormFinder, the lower the $M$ value, the higher the gene stability (Figure 2). GAPDH and EFA1 were most stable under biotic stress, 18S and CYPF stable under bacterial blight, BTUB and CYPF stable under wilt infection, EFA1 and ATUB stable under nematode infection, BTUB and EFA1stable under abiotic stress (Table 5). To determine the optimal number of reference genes for qPCR normalization for different stress in pomegranate, the average pairwise variation was calculated 
between two consecutive normalization factors $(\mathrm{Vn} / \mathrm{Vn}+1$, where $\mathrm{n}$ represents the reference gene number) across individual stress. According to Vandesompele and colleagues, recommend $\mathrm{Vn} / \mathrm{Vn}+1$ cut-off should be less than 0.15 , although this threshold should not be regarded as too stringent. The results exhibited that the $\mathrm{Vn} / \mathrm{Vn}+1$ values for different stress were below the cut-off value of 0.15 (Figure 3 ), except for biotic stress, which indicated that two reference genes would be sufficient for normalization of qPCR analysis in pomegranate.

\section{Comprehensive ranking by RefFinder}

RefFinder is a web-based interface, which calculates the geometric mean for each reference gene based on ranks calculated by other approaches. According to RefFinder expression stability of all reference genes were sorted according to the geometric mean (Table 6). Reference genes with the lowest geometric mean are considered the most stable. GAPDH ranked the most stable gene for the biotic stress sample group with a stability value of 1.86 . 18S rRNA for wilt infected samples with a stability value of 1.46 . Under bacterial blight infection, CYPF showed the least stability value (1.86).

\section{Discussion}

In the post-genomic era, various omics approaches have empowered us to understand the molecular mechanisms underlying the defence response of plants subjected to various stress. qPCR is the most widely used technique to study the molecular mechanisms of plant stress responses by analysing gene expression. However, gene expression studies are affected by several factors such as variation in RNA integrity from sample to sample, the variation in reverse transcriptase efficiency, and the quantity of cDNA template in each PCR reaction. Hence, normalization of target gene expression level against a stably expressed reference gene can eliminate all kinds of variation across samples [22]. The accuracy of the qPCR results strongly depends on selecting one or more reference genes that are stably expressed across different tissue and experimental conditions. Thus, in the present study, eight commonly used reference genes (EFA1, CYPF, UBQ, $\beta T U B$, aTUB, GAPDH, 18S, and PPCT) were used for evaluating their expression stability under both biotic (Bacterial blight, wilt, and nematode) and abiotic (cold and moisture stress) stress conditions in pomegranate.

The primer pairs specificity of the RG's was confirmed by melt curve by qPCR and agarose gel electrophoresis analysis (Fig. 1 and S1). The amplification efficiency of all RGs exhibited between 92.1 to 103 and $r 2 \geq 0.99$, considered acceptable [24, 25]. Expression stability of all RGs was estimated using different statistical algorithms such as $\Delta \mathrm{Ct}$, BestKeeper, NormFinder, and geNorm. These methods use distinct statistical algorithm procedures and have their advantages and drawbacks [26]. However, geNorm has been considered the best algorithm for identifying stable RG and it is highly sensitive for co-regulation compared to norm finder [27, 28]. According to geNorm, EFA1 was found to be a stable gene under biotic stress and abiotic stress. Similarly, in $\Delta$ the Ct method, EFA1 exhibited high stability across different stress conditions than other RGs in pomegranate. EFA1 was considered stable RG in Eucalyptus globulus during cold acclimation, and it has a relatively close taxonomic relationship with pomegranate based on comparative genomic analysis [29]. EFA1 also reported being a stable RG in different crops such as Cucumber [30], Tobacco under abiotic stress [31], Maize for abiotic and hormonal treatments [32], Perlmillet under abiotic stress [33]. RefFinder provides consensus expression stability values for RGs by combining other statistical algorithm methods such as $\Delta \mathrm{Ct}$, BestKeeper, NormFinder, and geNorm. Comprehensive ranking by RefFinder indicated that EF-1a was the most suitable reference gene for nematode infection and abiotic stress, CYPF for bacterial blight, $18 \mathrm{~S}$ for wilt infection, and GAPDH for biotic stress. Interestingly, 18S was the most stable RG ranked by all other methods under wilt infection, except geNorm. 18S rRNA was also reported to be stable under different stress conditions in crops such as eggplant [34] in tea plants (Camellia sinensis) exposed to Zn stress [35]. However, few studies have reported that due to a higher abundance of 18S rRNA transcripts than the target gene in the tissue, it is difficult to subtract the baseline value in qRT-PCR accurately [36-38]. Though the reference gene's stable expression is important in qPCR normalization, 18S rRNA cannot be considered a bad gene for normalization [23]. It can be used as the reference gene for those target genes with high expression under certain environmental conditions [36].

Using a single RG for normalization will affect the accuracy of calculating the target gene's expression [39]. Hence, using two or more RGs or using a single, highly stable RG for normalization would increase the accuracy of knowing the target gene's exact expression in a given sample. The geNorm algorithm determined the optimal number of reference genes required for normalization in pomegranate under different stress conditions. With a threshold of 0.15 , two reference genes were sufficient for normalization under wilt, bacterial blight, nematode, and abiotic stress. More than two RGs are required to normalize under biotic stress (pooled samples of all biotic stress). In biotic stress, the samples' complexity may result in higher variability in the expression of RGs. However, using more RGs would help to reach optimum results.

\section{Declarations}

\section{Conflict of Interest}

The authors of this article have no financial or other conflicts of interest to declare.

\section{Ethical approval}


The present manuscript has not been published anywhere else in the online or printed version. The author and corresponding author have no restrictions on data availability sharing, literature and all the software were collected from public sources. The manuscript data, illustrations or figures, and any other materials do not infringe any existing copyright or other rights of anyone.

\section{Author contribution}

P.D. designed the experiment and drafted the manuscript and did molecular experiments and data analysis. P.K. carried out all pathogen isolation, challenge inoculation, stress induction, and molecular experiments. M.S.D helped in conducting the green-house experiment, maintenance of pomegranate plants, and raising from the seedling. M.G Supervised and guided molecular lab experiments and edited the manuscript

\section{Acknowledgment}

The authors are thankful to the University of Horticultural Sciences, Bagalkot for providing support to the experiment. The author also thankful to the Science and Engineering Research Board (SERB), Dept. of Science and Technology, Govt. of India for providing awarded to the first author as National Postdoctoral Fellowship (NPDF) (PDF/2016/002924).

\section{Research involving human and animal participants}

This article does not contain any studies conducted on human or animal subjects.

\section{References}

1. Prasad D, Kunnaiah R (2014) Punica granatum: A review on its potential role in treating periodontal disease. Journal of Indian Society of Periodontology 18(4):428

2. Hingorani M, Mehta P (1952) Bacterial leaf spot of pomegranate. Indian Phytopathol 5:55-56

3. Somasekhara Y (1999) New record of Ceratocystis fimbriata causing wilt of pomegranate in India. Plant Dis 83(4):400-400

4. Pourghayoumi M, Bakhshi D, Rahemi M, Kamgar-Haghighi AA, Aalami A (2017) The physiological responses of various pomegranate cultivars to drought stress and recovery in order to screen for drought tolerance. Sci Hortic 217:164-172

5. Bustin S (2002) INVITED REVIEW Quantification of mRNA using real-time reverse transcription PCR (RT-PCR): trends and problems. J Mol Endocrinol 29:23-39

6. Gachon C, Mingam A, Charrier B (2004) Real-time PCR: what relevance to plant studies? J Exp Bot 55(402):1445-1454

7. Kim B-R, Nam H-Y, Kim S-U, Kim S-I, Chang Y-J (2003) Normalization of reverse transcription quantitative-PCR with housekeeping genes in rice. Biotechnol Lett 25(21):1869-1872

8. Marum L, Miguel A, Ricardo CP, Miguel C (2012) Reference gene selection for quantitative real-time PCR normalization in Quercus suber. PloS one 7(4):e35113

9. Qi J, Yu S, Zhang F, Shen X, Zhao X, Yu Y, Zhang D (2010) Reference gene selection for real-time quantitative polymerase chain reaction of mRNA transcript levels in Chinese cabbage (Brassica rapa L. ssp. pekinensis). Plant Molecular Biology Reporter 28(4):597-604

10. Doddaraju P, Kumar P, Gunnaiah R, Gowda AA, Lokesh V, Pujer P, Manjunatha G (2019) Reliable and early diagnosis of bacterial blight in pomegranate caused by Xanthomonas axonopodis pv. punicae using sensitive PCR techniques. Scientific reports 9(1):1-9

11. Harel-Beja R, Tian L, Freilich S, Habashi R, Borochov-Neori H, Lahav T, Trainin T, Doron-Faigenboim A, Ophir R, Bar-Ya'akov I (2019) Gene expression and metabolite profiling analyses of developing pomegranate fruit peel reveal interactions between anthocyanin and punicalagin production. Tree Genetics Genomes 15(2):1-13

12. Khaksar G, Tabatabaei BES, Arzani A, Ghobadi C, Ebrahimie E (2015) Functional analysis of a pomegranate (Punica granatum L.) MYB Transcription factor involved in the regulation of anthocyanin biosynthesis. Iranian journal of biotechnology 13(1):17

13. Martinelli F, Scalenghe R, Davino S, Panno S, Scuderi G, Ruisi P, Villa P, Stroppiana D, Boschetti M, Goulart LR (2015) Advanced methods of plant disease detection. A review. Agron Sustain Dev 35(1):1-25

14. Khan AL, Asaf S, Lee I-J, Al-Harrasi A, Al-Rawahi A (2018) First reported chloroplast genome sequence of Punica granatum (cultivar Helow) from Jabal Al-Akhdar, Oman: phylogenetic comparative assortment with Lagerstroemia. Genetica 146(6):461-474

15. Qin G, Xu C, Ming R, Tang H, Guyot R, Kramer EM, Hu Y, Yi X, Qi Y, Xu X (2017) The pomegranate (Punica granatum L.) genome and the genomics of punicalagin biosynthesis. Plant J 91(6):1108-1128

16. Sharma K, Sharma J, Jadhav V (2015) Recent Developments in Bacterial Blight of Pomegranate and Its Management. In: Recent Advances in the Diagnosis and Management of Plant Diseases. Springer, pp 119-126

17. Hutangura P, Jones M, Heinrich T (1998) Optimisation of culture conditions for in vitro infection of tomato with the root-knot nematode Meloidogyne javanica. Australas Plant Pathol 27(2):84-89

18. Udayakumar M, Sheshshayee M, Nataraj K (1998) Why has breeding for water use efficiency not been successful? An analysis and alternate approach to exploit this trait for crop improvement. Curr Sci 74(11):994-1000

Page $6 / 12$ 
19. Pfaffl MW (2001) A new mathematical model for relative quantification in real-time RT-PCR. Nucleic acids research 29(9):e45-e45

20. Walker NJ (2002) A technique whose time has come. Science 296(5567):557-559

21. Andersen CL, Jensen JL, Ørntoft TF (2004) Normalization of real-time quantitative reverse transcription-PCR data: a model-based variance estimation approach to identify genes suited for normalization, applied to bladder and colon cancer data sets. Cancer research 64(15):52455250

22. Pfaffl MW, Tichopad A, Prgomet C, Neuvians TP (2004) Determination of stable housekeeping genes, differentially regulated target genes and sample integrity: BestKeeper-Excel-based tool using pair-wise correlations. Biotechnol Lett 26(6):509-515

23. Vandesompele J, De Preter K, Pattyn F, Poppe B, Van Roy N, De Paepe A, Speleman F (2002) Accurate normalization of real-time quantitative RTPCR data by geometric averaging of multiple internal control genes. Genome biology 3(7):1-12

24. Adams P (2006) Data analysis and reporting. Real Time PCR (Dorak MT (ed)) New York. Taylor \& Francis Group

25. Biassoni R, Raso A (2016) Quantitative real-time PCR. Springer

26. Goulao LF, Fortunato AS, Ramalho JC (2012) Selection of Reference Genes for Normalizing Quantitative Real-Time PCR Gene Expression Data with Multiple Variables in Coffea spp. Plant Molecular Biology Reporter 30(3):741-759

27. Gutierrez L, Mauriat M, Guénin S, Pelloux J, Lefebvre JF, Louvet R, Rusterucci C, Moritz T, Guerineau F, Bellini C (2008) The lack of a systematic validation of reference genes: a serious pitfall undervalued in reverse transcription-polymerase chain reaction (RT-PCR) analysis in plants. Plant biotechnology journal 6(6):609-618

28. Jain M, Nijhawan A, Tyagi AK, Khurana JP (2006) Validation of housekeeping genes as internal control for studying gene expression in rice by quantitative real-time PCR. Biochem Biophys Res Commun 345(2):646-651

29. Yuan Z, Fang Y, Zhang T, Fei Z, Han F, Liu C, Liu M, Xiao W, Zhang W, Wu S (2018) The pomegranate (Punica granatum L.) genome provides insights into fruit quality and ovule developmental biology. Plant biotechnology journal 16(7):1363-1374

30. Wan H, Zhao Z, Qian C, Sui Y, Malik AA, Chen J (2010) Selection of appropriate reference genes for gene expression studies by quantitative realtime polymerase chain reaction in cucumber. Anal Biochem 399(2):257-261

31. Schmidt GW, Delaney SK (2010) Stable internal reference genes for normalization of real-time RT-PCR in tobacco (Nicotiana tabacum) during development and abiotic stress. Mol Genet Genomics 283(3):233-241

32. Lin Y, Zhang C, Lan H, Gao S, Liu H, Liu J, Cao M, Pan G, Rong T, Zhang S (2014) Validation of potential reference genes for qPCR in maize across abiotic stresses, hormone treatments, and tissue types. PloS one 9(5):e95445

33. Shivhare R, Lata C (2016) Selection of suitable reference genes for assessing gene expression in pearl millet under different abiotic stresses and their combinations. Scientific reports 6(1):1-12

34. Zhou X, Liu J, Zhuang Y (2014) Selection of appropriate reference genes in eggplant for quantitative gene expression studies under different experimental conditions. Sci Hortic 176:200-207

35. Wang M-L, Li Q-H, Xin H-H, Chen X, Zhu X-J, Li X-H (2017) Reliable reference genes for normalization of gene expression data in tea plants (Camellia sinensis) exposed to metal stresses. PloS one 12(4):e0175863

36. Kozera B, Rapacz M (2013) Reference genes in real-time PCR. J Appl Genet 54(4):391-406

37. Tong Z, Gao Z, Wang F, Zhou J, Zhang Z (2009) Selection of reliable reference genes for gene expression studies in peach using real-time PCR. BMC Mol Biol 10(1):1-13

38. Wieczorek P, Wrzesińska B, Obrępalska-Stęplowska A (2013) Assessment of reference gene stability influenced by extremely divergent disease symptoms in Solanum lycopersicum L. J Virol Methods 194(1-2):161-168

39. Zhu J, He F, Song S, Wang J, Yu J (2008) How many human genes can be defined as housekeeping with current expression data? BMC Genomics 9(1):1-11

\section{Tables}

Table 1: Primer sequences and amplicon characteristics for selected reference genes in pomegranate 


\begin{tabular}{|c|c|c|c|c|c|c|c|}
\hline \multirow[b]{2}{*}{ Gene Name } & \multirow{2}{*}{$\begin{array}{l}\text { Gene } \\
\text { symbol }\end{array}$} & \multicolumn{2}{|l|}{ Primer sequence $\left(5^{\prime}-3^{\prime}\right)$} & \multirow[t]{2}{*}{ Accession ID } & \multirow{2}{*}{$\begin{array}{l}\text { Amplicon } \\
\text { length }\end{array}$} & \multirow[t]{2}{*}{$E(\%)^{*}$} & \multirow[t]{2}{*}{$\mathrm{R}^{2} \otimes$} \\
\hline & & Forward & Reverse & & & & \\
\hline $\begin{array}{l}\text { 18S Ribosomal } \\
\text { RNA }\end{array}$ & $\begin{array}{l}18 \mathrm{~S} \\
\text { rRNA }\end{array}$ & GTTGATCCTGCCAGTAGTC & CCGAGTAGCAGATACCATC & XR_004152599 & 136 & 95.72 & 0.999 \\
\hline a-Tubulin & $a-T U B$ & TCCAGGGCTTCCTTGTCTTC & TTGGGGAGAGGGGGTAAAC & XM_031521521 & 132 & 99.43 & 0.995 \\
\hline$\beta$-Tubulin & $\beta$-TUB & TGAGGAAGGAGGCTGAGAAC & TTGGGTGATGGGAACACTG & XM_031530647 & 163 & 92.10 & 0.992 \\
\hline Cyclophilin & CYP & TGTGCCAAGGTGGTGACTTC & CGGTGTGCTTCCTGATGAAG & XM_031537407 & 99 & 99.98 & 0.998 \\
\hline $\begin{array}{l}\text { Peptidyl-prolyl } \\
\text { cis-trans } \\
\text { isomerase }\end{array}$ & PPCT & GAACTTCGCCCCGTAGATC & AAGCСССТCСАCTACAAGG & XM_031537407 & 120 & 103.04 & 0.995 \\
\hline $\begin{array}{l}\text { Elongation } \\
\text { Factor 1- a }\end{array}$ & EF1-a & TGGATGGCAGGGACAAGAC & GGGTGGCAAGTGAATCGTG & XM_031517615 & 134 & 95.28 & 0.999 \\
\hline $\begin{array}{l}\text { Ubiquitin- } \\
\text { conjugating } \\
\text { enzyme }\end{array}$ & UBQCE & ATTCTCCGCTGGTTTGGTG & AGGGCTGTTGGGATAGTTGG & XM_031545647 & 136 & 99.97 & 0.997 \\
\hline $\begin{array}{l}\text { Glyceraldehyde } \\
\text { 3-phosphate } \\
\text { dehydrogenase }\end{array}$ & GAPDH & AAGGGTGGTGCWAAGAAGGT & CCCCACTCRTTGTCRTACCA & XM_031549027 & 230 & 90.65 & 0.981 \\
\hline
\end{tabular}

*Measure of RT-qPCR efficiency calculated by standard curve method, $\otimes$ Regression co-efficient calculated from the regression line in the standard curve

Table 2: Expression stability of eight reference genes in pomegranate analyzed using the Delta-Ct algorithm, SD-standard deviation.

\begin{tabular}{|c|c|c|c|c|c|c|c|c|c|c|}
\hline \multirow[t]{2}{*}{ Rank } & \multicolumn{2}{|c|}{ Biotic stress } & \multicolumn{2}{|c|}{ Bacterial blight } & \multicolumn{2}{|l|}{ Wilt } & \multicolumn{2}{|c|}{ Nematode infected } & \multicolumn{2}{|c|}{ Abiotic stress } \\
\hline & Genes & SD & Genes & SD & Genes & SD & Genes & SD & Genes & SD \\
\hline 1 & EFA1 & 1.28 & EFA1 & 0.83 & $18 \mathrm{~s}$ & 1.27 & EFA1 & 1.12 & EFA1 & 0.47 \\
\hline 2 & CYPF & 1.29 & $18 s$ & 0.87 & CYPF & 1.31 & aTUB & 1.13 & $\beta T U B$ & 0.50 \\
\hline 3 & GAPDH & 1.63 & CYPF & 0.88 & UBQ & 1.35 & $\beta$ TUB & 1.14 & aTUB & 0.53 \\
\hline 4 & aTUB & 1.64 & РPCT & 1.02 & GAPDH & 1.39 & UBQ & 1.19 & UBQ & 0.53 \\
\hline 5 & UBQ & 1.7 & GAPDH & 1.05 & EFA1 & 1.42 & CYPF & 1.24 & РPCT & 0.66 \\
\hline 6 & $\beta T U B$ & 2.01 & $\beta T U B$ & 1.06 & $\beta T U B$ & 1.42 & РPCT & 1.35 & GAPDH & 0.68 \\
\hline 7 & РPCT & 2.04 & UBQ & 1.14 & aTUB & 1.81 & GAPDH & 2.02 & $18 s$ & 0.77 \\
\hline 8 & $18 s$ & 2.16 & aTUB & 1.81 & РPCT & 2.85 & $18 s$ & 2.67 & CYPF & 0.81 \\
\hline
\end{tabular}

Table 3: Expression stability of eight reference genes in pomegranate analyzed using the Best keeper algorithm, SD- Average of standard deviation. 


\begin{tabular}{|c|c|c|c|c|c|c|c|c|c|c|}
\hline \multirow[t]{2}{*}{ Rank } & \multicolumn{2}{|c|}{ Biotic stress } & \multicolumn{2}{|c|}{ Bacterial blight } & \multicolumn{2}{|l|}{ Wilt } & \multicolumn{2}{|c|}{ Nematode infected } & \multicolumn{2}{|c|}{ Abiotic stress } \\
\hline & Genes & SD & Genes & SD & Genes & SD & Genes & SD & Genes & SD \\
\hline 1 & GAPDH & 0.22 & GAPDH & 0.73 & $18 s$ & 0.28 & $\beta T U B$ & 0.28 & aTUB & 0.05 \\
\hline 2 & UBQ & 0.28 & CYPF & 0.79 & EFA1 & 0.49 & aTUB & 0.46 & EFA1 & 0.19 \\
\hline 3 & EFA1 & 0.87 & $18 \mathrm{~S}$ & 0.79 & UBQ & 0.85 & EFA1 & 0.47 & GAPDH & 0.21 \\
\hline 4 & $\beta T U B$ & 1.00 & PPCT & 0.93 & CYPF & 0.87 & UBQ & 0.49 & UBQ & 0.24 \\
\hline 5 & CYPF & 1.09 & EFA1 & 1.08 & GAPDH & 0.97 & CYPF & 0.50 & $\beta T U B$ & 0.33 \\
\hline 6 & aTUB & 1.48 & $\beta T U B$ & 1.68 & $\beta T U B$ & 1.02 & PPCT & 0.51 & РPCT & 0.50 \\
\hline 7 & РPCT & 1.93 & UBQ & 1.74 & aTUB & 1.09 & GAPDH & 1.35 & $18 s$ & 0.60 \\
\hline 8 & $18 \mathrm{~S}$ & 2.22 & aTUB & 2.52 & РPCT & 2.14 & $18 s$ & 2.03 & CYPF & 0.72 \\
\hline
\end{tabular}

Table 4: Expression stability of eight reference genes in pomegranate analyzed using the NormFinder algorithm, SV- stability value.

\begin{tabular}{|c|c|c|c|c|c|c|c|c|c|c|}
\hline \multirow[t]{2}{*}{ Rank } & \multicolumn{2}{|c|}{ Biotic stress } & \multicolumn{2}{|c|}{ Bacterial blight } & \multicolumn{2}{|l|}{ Wilt } & \multicolumn{2}{|c|}{ Nematode infected } & \multicolumn{2}{|c|}{ Abiotic stress } \\
\hline & Genes & SV & Genes & SV & Genes & SV & Genes & sV & Genes & SV \\
\hline 1 & CYPF & 0.25 & EFA1 & 0.12 & $18 S$ & 0.28 & $\beta T U B$ & 0.21 & EFA1 & 0.07 \\
\hline 2 & EFA1 & 0.25 & CYPF & 0.57 & EFA1 & 0.40 & CYPF & 0.41 & $\beta T U B$ & 0.17 \\
\hline 3 & aTUB & 1.13 & $18 s$ & 0.58 & CYPF & 1.03 & aTUB & 0.48 & UBQ & 0.29 \\
\hline 4 & GAPDH & 1.16 & $\beta T U B$ & 0.62 & UBQ & 1.04 & EFA1 & 0.52 & aTUB & 0.31 \\
\hline 5 & UBQ & 1.34 & PPCT & 0.77 & GAPDH & 1.20 & UBQ & 0.64 & РPCT & 0.52 \\
\hline 6 & $\beta T U B$ & 1.73 & UBQ & 0.80 & $\beta T U B$ & 1.25 & РPCT & 0.67 & GAPDH & 0.58 \\
\hline 7 & РPCT & 1.76 & GAPDH & 0.87 & aTUB & 1.35 & GAPDH & 1.91 & $18 \mathrm{~S}$ & 0.65 \\
\hline 8 & $18 \mathrm{~S}$ & 1.85 & aTUB & 1.74 & РPCT & 2.82 & $18 S$ & 2.61 & CYPF & 0.70 \\
\hline
\end{tabular}

Table 5: Expression stability of eight reference genes in pomegranate analyzed using the geNorm algorithm, M- stability value.

\begin{tabular}{|c|c|c|c|c|c|c|c|c|c|c|}
\hline \multirow[t]{2}{*}{ Rank } & \multicolumn{2}{|l|}{ Biotic stress } & \multicolumn{2}{|c|}{ Bacterial blight } & \multicolumn{2}{|l|}{ Wilt } & \multicolumn{2}{|c|}{ Nematode infected } & \multicolumn{2}{|l|}{ Abiotic stress } \\
\hline & Genes & $M$ & Genes & $M$ & Genes & $M$ & Genes & $M$ & Genes & $M$ \\
\hline 1 & GAPDH/EFA1 & 0.29 & 18S/CYPF & 0.20 & BTUB/CYPF & 0.22 & EFA1/ATUB & 0.11 & BTUB/EFA1 & 0.18 \\
\hline 2 & UBQ & 0.55 & GAPDH & 0.30 & GAPDH & 0.24 & UBQ & 0.29 & ATUB & 0.31 \\
\hline 3 & aTUB & 0.68 & РPCT & 0.40 & UBQ & 0.28 & BTUB & 0.58 & UBQ & 0.35 \\
\hline 4 & $18 \mathrm{~S}$ & 0.77 & EFA1 & 0.46 & $18 S$ & 0.60 & CYPF & 0.72 & РPCT & 0.39 \\
\hline 5 & PPCT & 0.86 & $\beta T U B$ & 0.67 & EFA1 & 0.86 & PPCT & 0.82 & GAPDH & 0.44 \\
\hline 6 & $\beta T U B$ & 0.99 & UBQ & 0.85 & ATUB & 1.17 & GAPDH & 1.06 & CYPF & 0.53 \\
\hline 7 & CYPF & 1.29 & aTUB & 1.15 & РPCT & 1.55 & $18 S$ & 1.43 & $18 \mathrm{~S}$ & 0.58 \\
\hline
\end{tabular}

Table 6: Expression stability of eight reference genes in pomegranate analyzed using the Ref finder algorithm.GM-Geo mean of ranking values. 


\begin{tabular}{|c|c|c|c|c|c|c|c|c|c|c|}
\hline \multirow[t]{2}{*}{ Rank } & \multicolumn{2}{|c|}{ Biotic stress } & \multicolumn{2}{|c|}{ Bacterial blight } & \multicolumn{2}{|l|}{ Wilt } & \multicolumn{2}{|c|}{ Nematode infected } & \multicolumn{2}{|c|}{ Abiotic stress } \\
\hline & Genes & GM & Genes & GM & Genes & GM & Genes & GM & Genes & GM \\
\hline 1 & GAPDH & 1.86 & CYPF & 1.86 & $18 S$ & 1.49 & EFA1 & 1.86 & EFA1 & 1.18 \\
\hline 2 & EFA1 & 2.06 & $18 \mathrm{~S}$ & 2.06 & CYPF & 2.21 & aTUB & 1.86 & $\beta T U B$ & 2.11 \\
\hline 3 & CYPF & 2.51 & EFA1 & 2.23 & EFA1 & 3.31 & $\beta T U B$ & 1.86 & aTUB & 2.44 \\
\hline 4 & UBQ & 2.65 & GAPDH & 3.20 & UBQ & 3.46 & UBQ & 3.93 & UBQ & 3.72 \\
\hline 5 & aTUB & 4.35 & РPCT & 4.22 & $\beta T U B$ & 3.83 & CYPF & 3.97 & GAPDH & 4.82 \\
\hline 6 & $\beta T U B$ & 5.42 & $\beta T U B$ & 5.42 & GAPDH & 4.16 & РPCT & 6 & РPCT & 5.47 \\
\hline 7 & РPCT & 7 & UBQ & 6.73 & aTUB & 7 & GAPDH & 7 & $18 \mathrm{~S}$ & 7 \\
\hline 8 & $18 S$ & 8 & aTUB & 8 & РPCT & 8 & $18 S$ & 8 & CYPF & 8 \\
\hline
\end{tabular}

\section{Figures}
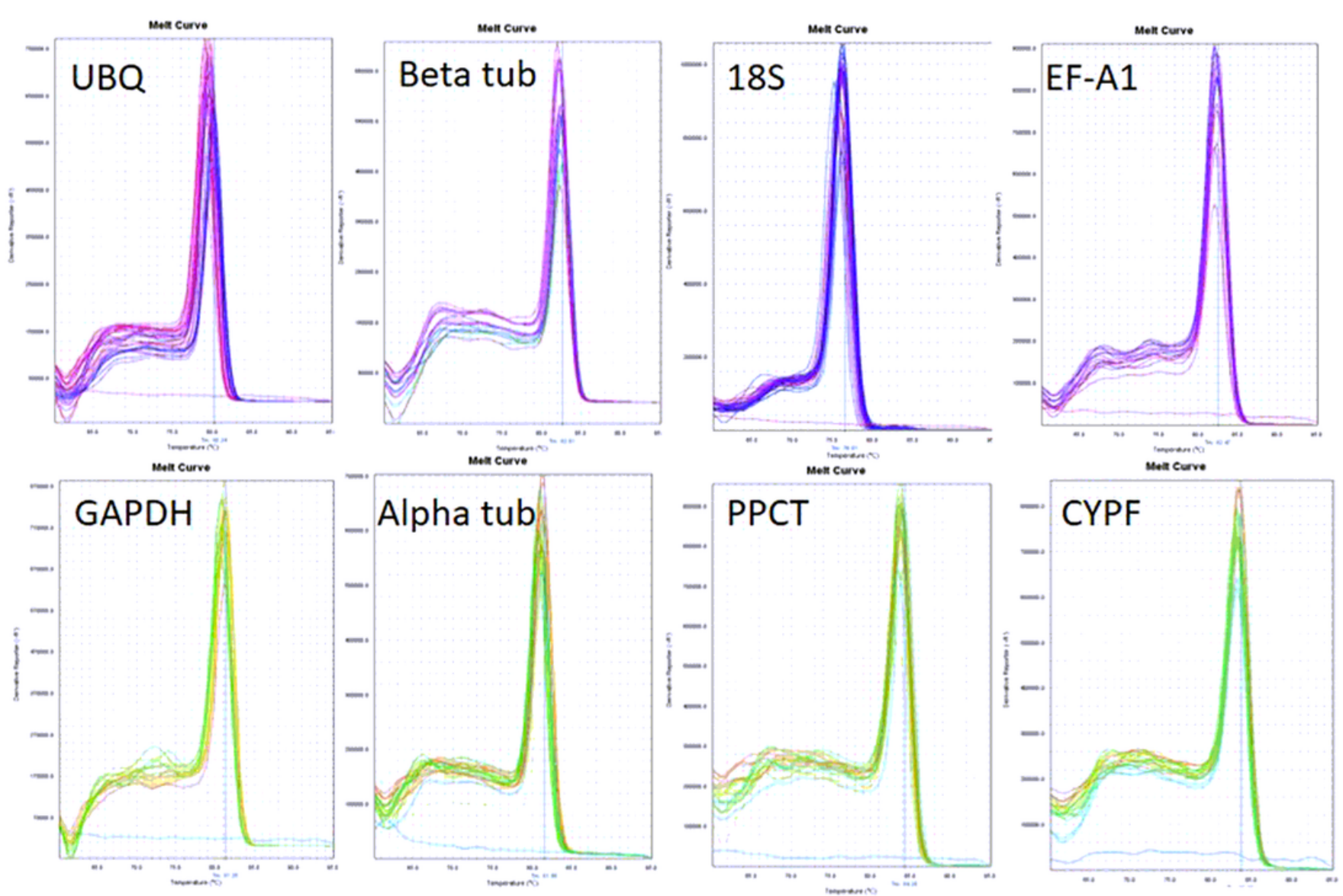

\section{Figure 1}

Melting curves of 8 candidate reference genes in Pomegranate. Melting temperatures were visualized by plotting the negative first derivative of fluorescence relative to the temperature in Celsius [-(d/dT)]. 

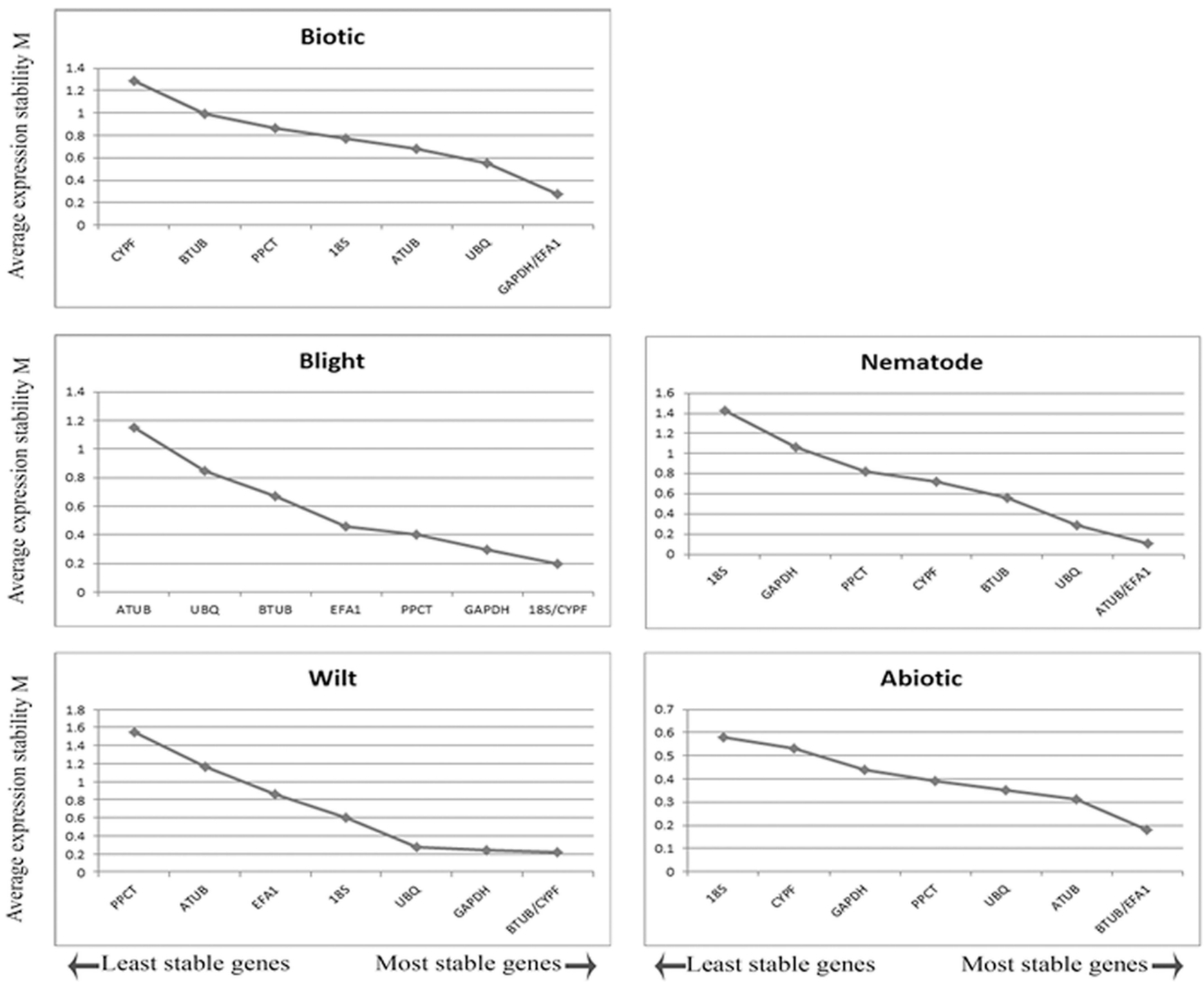

Figure 2

Average expression stability values of reference genes calculated by geNorm during different biotic and abiotic stress. 


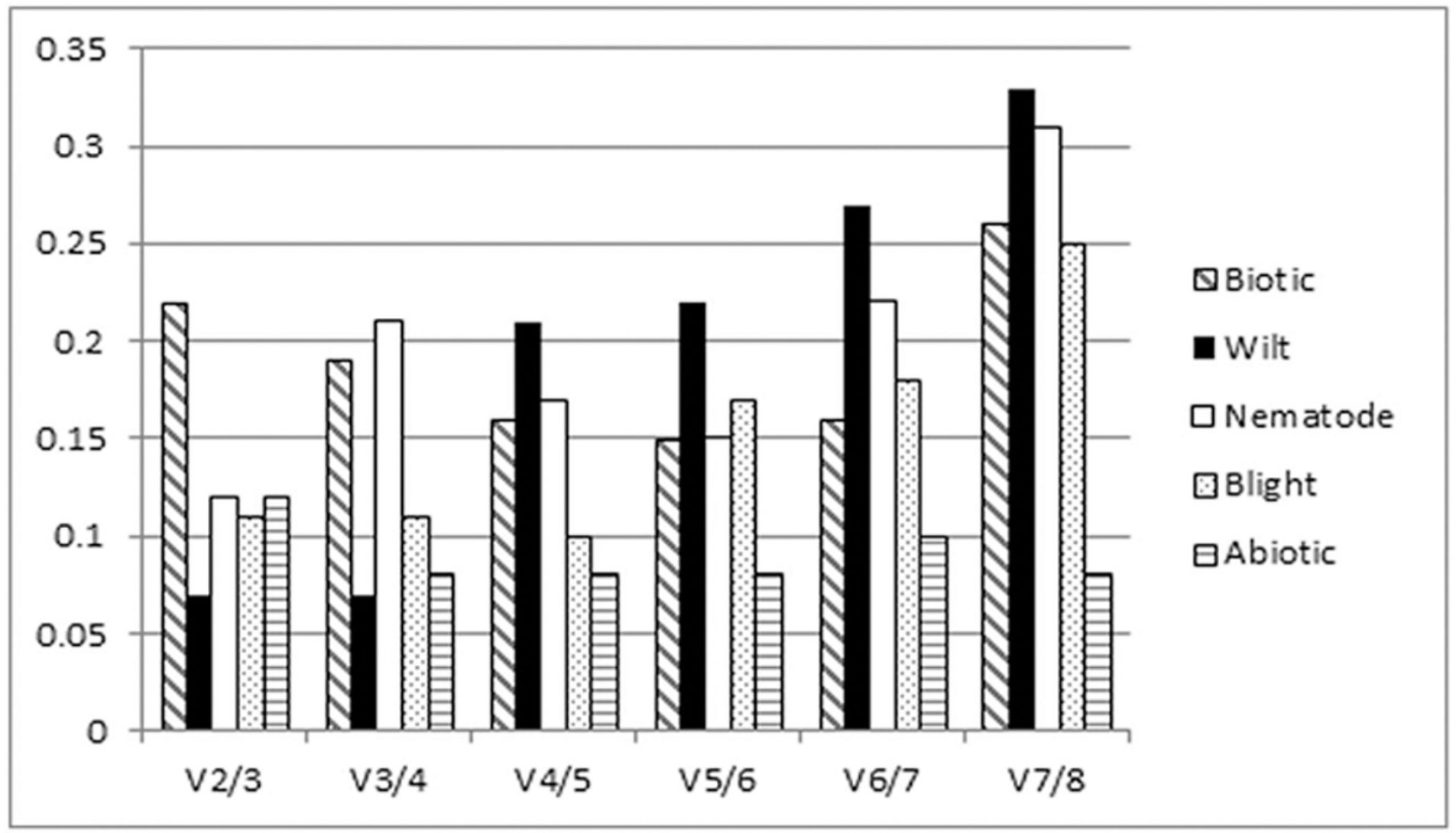

Figure 3

The optimal number of reference genes for accurate normalization was calculated by geNorm during different biotic and abiotic stress. Pairwise variation $(\mathrm{Vn} / \mathrm{Vn}+1)$ analysis of eight candidate reference genes analyzed in five different conditions.

\section{Supplementary Files}

This is a list of supplementary files associated with this preprint. Click to download.

- S1fig.tif 